\title{
WHAT IS ARCHITECTURAL RESEARCH TODAY AND WHERE IS THE GROUND?
}

\author{
A B S T R A C T
}

Why make large structures from rubber bands with students of architecture? How does such an endeavour relate to architectural education? And if rubber band structures are neither buildings, nor models of buildings, but experiments of some sort, what kind of knowledge do they generate relevant to construction industry and the built environment? These are some of the issues which have surfaced at the conference "ISSUES? Concerning the projects of Peter Eisenman" held in Belgrade in November 2013. They are related to a string of design research projects recently completed at the University of Belgrade - Faculty of Architecture and documented in the thematic volume of Serbian Architectural Journal titled "Architectural Education in the Post Digital Age" which was published independently but almost concurrently with the conference. In continuity with arguments given in that publication, this paper will provide a brief overview of some relevant and generally accepted theories and manifestos related to design research methodologies, providing grounds for the current work at the Faculty of Architecture, University of Belgrade. 


\section{INTRODUCTION}

A series of design research projects from the University of Belgrade - Faculty of Architecture was presented at the conference concerning the work of Peter Eisenman held in Belgrade, November 2013 (Figure 1). The format of the conference allowed for the discussion after each thematic group of presentations. The conversation following the segment of the conference titled "Digital vs. Analogue", which included the above mentioned presentation, took an unexpected turn when Mr. Eisenman posed the following question: "Where is the ground?" The dilemma implied an important topic of Mr. Eisenman's earlier work, concerned with the actual treatment of the terrain and importance of the ground to architectural projects. At the same time, Mr. Eisenman's question also teased out another even greater dilemma related to the very purpose of any such research in architecture, whereby the actual meaning of the question could be rephrased into: On what grounds does this work stand? A satisfactory answer was never given during the debate. In response, this paper will provide a brief overview of some of the relevant and generally accepted theories and manifestos related to design research methodologies, providing context and foundation for the work at the University of Belgrade - Faculty of Architecture.

The event in Belgrade may be seen as a sequel to "Stocktaking", an exciting issue of the Log magazine guest edited by Peter Eisenman and Anthony Vidler (2013), with the contribution from a number of prominent practitioners, theoreticians and educators who were invited to speak in vivo in November 2013. ${ }^{1}$ It is important to know that the publication edited by Eisenman and Vidler has the same title as a series of articles published by Reyner Banham in the Architectural Review in the 60's, all inspired by the straightforward question: "What is the state of architecture today?" At the time, Banham was concerned with the "growing schism between tradition and technology in architecture", a premise which is also recognized by Eisenman and Vidler for its relevance to the present day state of affairs in architectural practice, pedagogy, theory, and criticism. In its own right, this paper will discuss some of the emerging ways of working in architecture based on an overlap between design education, practice and research.

The idea for the topic of this paper comes from the experience generated in an educational setting which places emphasis on a specific form of knowledge development based on transferable skills in contrast to the more typically pursued practical and technical skills. It is based on the observation that traditional architectural education is most commonly structured around the design-based 


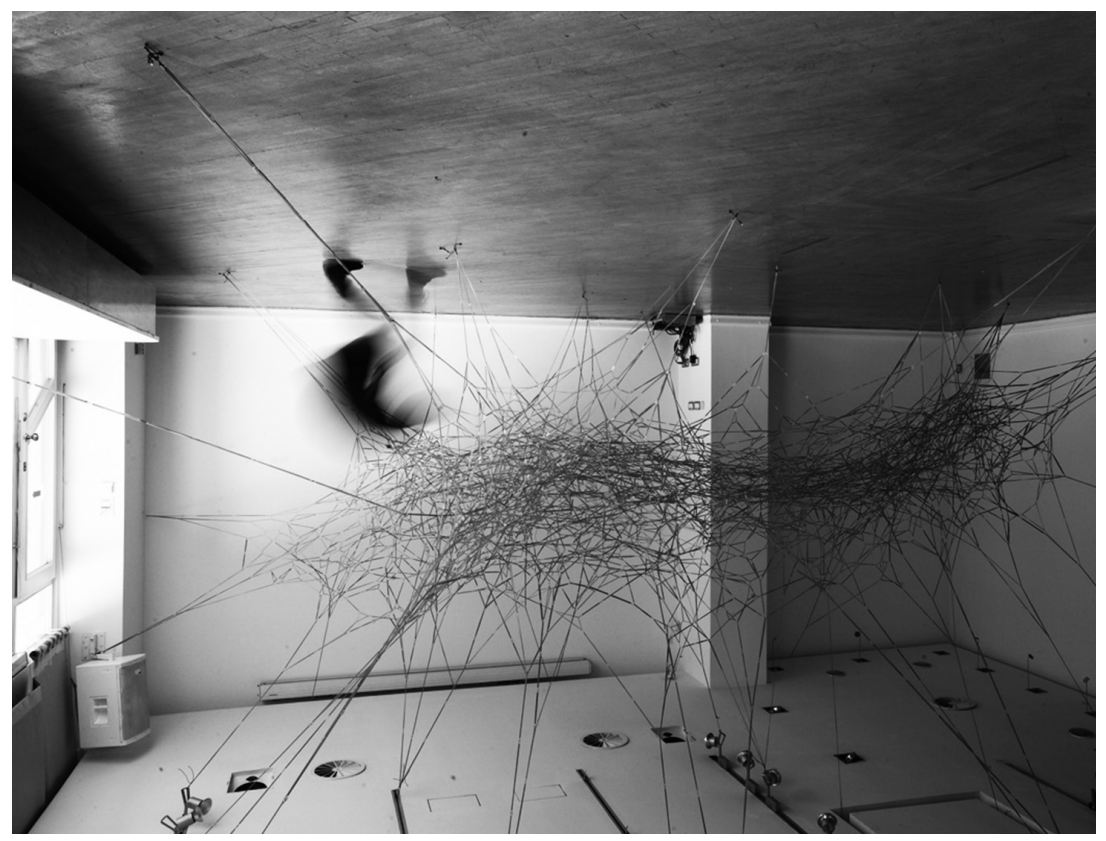

Figure 1. Design Research Project from the University of Belgrade - Faculty of Architecture: Prototypical model "Inconsistencies v.03", Inverted, O3one Art Space 2011. 
curriculum delivered in the studio-like setting, normally implying a version of teaching methodology which includes individual work on a programmatically determined and site specific project. In this context, research related activities are often separated from the design process. The early stages of the semester are generally reserved for research activities, most often regarded as a creative phase of the design process and a prelude to the actual design work. During the later stages of the semester, any research oriented efforts are considered more cautiously and often abandoned as they become counterproductive for the hard working student who is diligently working on numerous drawings leading toward a plausible architectural proposal. The research agenda, although frequently mentioned in the design curricula, often disintegrates under the complexity of the many decisions that students have to make and hardly ever remains visible and viable in their final work. In response, many schools of architecture are eager to test and introduce novel forms of education, placing greater emphasis on the relationship between research-based activities and design-led ways of learning. ${ }^{2}$ The set of design research projects from the University of Belgrade - Faculty of Architecture presented at the conference originates from the educational setting and provides an opportunity to probe further into the development of the teaching methodology which concentrates on installations, experiments and full scale models while maintaining design centered approach to architecture.

\section{WHAT IS ARCHITECTURAL RESEARCH?}

In an attempt to establish grounds for the current design research at the University of Belgrade - Faculty of Architecture, this paper focuses on some relevant and generally accepted theories and manifestos related to design research methodologies. The overview begins with Jeremy Till's memorandum, endorsed and publicised by RIBA, titled "What is architectural research? Three myths and one model", ${ }^{3}$ where he states that any kind of Research including architectural, is to be understood as an original investigation undertaken to gain knowledge and understanding; and that any good research can be identified by applying the triple test of: originality, significance and rigour. He also points out that architecture is a form of knowledge that can and should be developed through research. From this, it is easy to concur that architectural research is a method of inquiry, essential to the advancement of the discipline. Yet, Till also emphasises that there are frequent misconceptions and wrongdoings in this field worth revising for the benefit of further argument in this text. Firstly there is a belief that architecture is so special that no research methods applicable to other disciplines work in architecture, leading to impulsive and intuitive 
actions and the build up of self-referential arguments. The result may be that architecture becomes irrelevant and irresponsible. Secondly, many architectural researchers opt to turn to other disciplines for research mechanism. This may lead to architecture being lost between arts and sciences and the acceptance of research methodologies clearly not applicable to architecture. And thirdly, architects too easily like to believe that building is a form of research in its own right and that therefore design, including making and construction, is equal to research. This approach may be reductive in its nature and incapable of including many aspects of the design process such as representation, use and theoretical conceptions. By deducing that good building is not necessarily equal to a good research, Till opens up the debate on how to conduct architectural research since it is so central to the future of the discipline. He points out the growing divergence between academia and practice as the principal problem related to the purposes of architectural research. He sees that contemporary architectural "academia is inward looking with little public good, while present day practice is unable to communicate". He concludes that "practice has the raw data on which architectural knowledge is found, academia can release this potential through research". Till's recommendation is that architectural research should be closely connected to practice and advanced across three interconnected areas: "research into architectural process (design and construction), architectural products (completed objects) and architectural performance (occupation, social, environmental, cultural etc.)". Although the memorandum does not elaborate on how to research any of three identified areas, it provides a base for further review and discussion. The most important argument raised by Till is the disciplinary need to reconsider the relationship between practice and research.

\section{RESEARCH IN, THROUGH AND FOR ART AND DESIGN}

Another important reference for the current design research at the University of Belgrade - Faculty of Architecture is an older article, titled "Research in Art and Design" by Christopher Frayling. ${ }^{4}$ The author examines diverging relationship between research and design and points out that research is most commonly seen as an endeavour which "always involves going over the old territory", while design or practice, to maintain continuity with the former paragraph, "are of course concerned with the new". In response, Frayling believes that there are three different ways of going about the link between practice and research. He firstly suggests that there is research "into art and design", which is straightforward and could include different aspects such as: historical, aesthetic or perceptual, theoretical perspectives, social, political, 
cultural, technical, structural, etc. Secondly, he advocates that there is research "through art and design", which could be directed toward specific materials research or development of patents and procedures. And finally, he suggests there is research "for art and design", where the end products are artefacts and the thinking embodied in the artefacts, while the goal is communicable knowledge. Frayling's understanding of research "into art and design" corresponds with Till's vision of the architectural research based on the need to bring closer academia and practice, while two other ways of researching, "through and for art and design", stand for a more dubious association between them. The most important argument raised by Frayling is that the relationship between practice and research could be structural or even binding to the extent that it would be difficult to differentiate when one stops and the other begins, and precisely for this ambiguity it is important not to lose awareness about misconceptions and wrongdoings identified in the previous paragraph.

\section{RESEARCH BY DESIGN}

One possible way forward in developing the relationship between design and research lies in an attempt to define novel research methodologies, helping researches not to lose awareness of originality, significance and rigour while trying to establish links with the practice. Possibly the best hopes of today are resting with the research by design paradigm, although the debate of what it actually is remains wide open. There are many different and interesting ideas on what the term stands for. For instance, a conference titled "Architectural Research by Design: Unifying Academia and Practice through Research" held in Lisbon in 2014, suggested in its call that "the difference (between research and design research) is methodological, because one is research where the inquiry is leading to new understandings about and within the processes of design conception while the other is research about something that does not yet exist and which uses architectural practice as the research method". 5

A large segment of the contemporary EAAE Charter on Architectural Research (2011) is dedicated to the research by design paradigm. ${ }^{6}$ Interestingly, research by design is not referred to as a method in the Charter, instead it is described as "any kind of inquiry in which design is the substantial constituent of the research process". The EAAE states that "in research by design, the architectural design process forms the pathway through which new insights, knowledge, practices or products come into being. It generates critical inquiry through design work"; and concludes: "therefore research results are obtained by, and consistent with experience in practice". ${ }^{7}$ Importantly, the Charter points out that in addition to 
written and graphic outputs, research by design may also include: installations, experimental projects, design proposals, models and actual buildings. It is also important that the EAAE Charter insists on the ties between research and education, suggesting that the aim of architectural higher education is to develop a research disposition in students, and recommends that "valid architectural research outputs are as varied as the constantly growing range of research approaches". ${ }^{8}$ In many ways the Charter concurs with arguments and ideas presented by Till and Frayling. It states that research is essential and supports rapid expansion of the horizons of architectural experimentation according to the development of new technologies and media. Moreover, it stipulates that present day architectural practice is facing challenges of climate change, globalization, urbanization and social transformation that necessitate vital research. ${ }^{9}$

\section{PRACTICE BASED RESEARCH}

Not to be confused with the research by design paradigm, there are other noteworthy attempts to position architectural research in reference to architectural practice. One such initiative is the Framework for Practice Based Research developed at School of Architecture and Design at RMIT University and presented by the Dean, Richard Blythe. ${ }^{10}$ The approach assumes that a researcher/designer will continue working interruptedly in the future, that he or she will continue designing while researching. The framework is based on the analysis of the sequence of projects made over the period of time. Such sequence, established by the examination of similarities and individualities of a project, will form the basis for the reflection. At RMIT, the term "Familiar Resemblances" was coined to describe projects belonging to groups and sets. Blythe explicates that the term stands for an "urge that runs through sequence of projects" which is very difficult to describe in words, and sees that as a "tendency that drives the practice in particular direction". ${ }^{11} \mathrm{He}$ points out that the researcher/designer's task is to explicate what is going on and to reflect on his/her own body of ongoing work. He calls this "dynamic reflection" which forms the basis for the association between design and research. According to this framework, at the intersection of sets formed by similar projects, lie the key moments which may be related to other work and other designers with close ways of working. Blythe suggests that this is an opportunity to establish associations, reflect outwards, establish a critical path contributing to the body of knowledge, and concludes that the proposed framework may help expand boundaries of the disciplinary knowledge. ${ }^{12}$ 
THE GROUNDS FOR DESIGN RESEARCH

\section{AT UNIVERSITY OF BELGRADE - FACULTY OF ARCHITECTURE}

The series of design research projects from the University of Belgrade Faculty of Architecture presented at the conference concerning the work of Peter Eisenman held in Belgrade, November 2013 is positioned half way between the EAAE's Architectural Research declaration and RMIT's Framework for Practice Based Research. On one hand, presented artifacts demonstrate that the design is a substantial constituent of the research process, while on the other they show a certain sequence of projects which form the basis for reflection. Presented workflow demonstrates progress from particular theoretical positions, through material based or physical studies, to prototypical solutions and full scale models, while complying with the triple test of: originality, significance and rigour as suggested by Till. More detailed information about the workflow is given in a dedicated volume of Serbian Architectural Journal titled "Architectural Education in the Post Digital Age". ${ }^{13}$ The publication documents how several large scale installations were conceptualised and constructed within the specific scope of research ${ }^{1}$. In addition, that publication provides an overview of some groundbreaking design research projects recently conducted at several leading institutions in Europe. Importantly, none of the presented projects were referred to as buildings or models of buildings, but experiments aiming to generate knowledge and better understanding of complex spatial organisations, structures and environments. Techniques and methods of their conception, construction and use were copiously discussed to provide knowledge applicable to construction industry and better understanding of the built environment. A common thread between projects from the University of Belgrade - Faculty of Architecture and other educational institutions is an interest for cross disciplinary approach. Intriguing findings in different disciplines such as social science, economy and biology, although still untested and unexplored in contemporary architectural practice, are now finding their way into the contemporary architectural research. Phenomena such as: bottom-up, distributed, elastic, expandable, immaterial, immersive, inclusive, incongruous, mobile, nonlinear, non-hierarchical, participatory, permeable, polycentric, polyvalent, porous, recursive, relational, responsive, robust, saturated, smart, smooth, self-organizing, self-regulatory, soft, systemic, topological are all applicable to thinking about the spatial organisations, structures and environments of different scales and appear as recurring topics in the design research work at many recognized institutions concerned with architecture. The design research projects developed around such phenomena are probing into the development of the new tools, techniques 
and ways of working in architecture and they are much needed to understand the complexity of the contemporary built environment. The presented design research from the University of Belgrade - Faculty of Architecture suggested that such phenomena could lend themselves to becoming the topics for a string of experiments in architecture, a sequence of projects made over the period of time which will then offer a basis for reflection. In reference to the framework for practice based research developed at the School of Architecture and Design at RMIT, this approach suggests that the topic that drives the practice in a particular direction could be identified before the actual design research begins. The idea follows Fryling's recommendation that research through art and design could be directed toward specific materials research or development of patents and procedures, where the end products are: an artefact, thinking embodied in the artefact, and the communicable knowledge. within the specific scope of research at the University of Belgrade - Faculty of Architecture under the "4of7" label. The initiative which encompasses architectural practice, research and education, first started in 2007 with the agenda comprised of three overlapping areas of inquiry. Firstly, there is an idea of computing without computers, brought forward by Kostas Terzidis (2006): "Algorithms are not necessarily dependent on computers... This distinction is very important as it liberates, excludes, and dissociates the mathematical and logical process used for addressing the problem, from the machine that facilitates the implementation of those processes". He points out the difference between the terms "computation," implying a way of resolving a problem, and "computerization" suggesting a way of storing and processing data with a computer. In other words, understanding and applying computational logic may be done with the use of analogue means such as physical models, diagrams and drawings. Secondly, there is an urge to construct large scale models of the prototypical nature. This is supported by the historical development of the incentive which starts during the 70's with the establishment of laboratories for full-scale modeling in many architectural schools across the Northern Europe. The initiative then suddenly dies during the 90's with the appearance of the first commercially available systems for computer aided design and then widely established belief that virtual modeling would be a sufficient replacement for the physical models. 
More recently, the very same ambition comes to surface once again with the development of digital fabrication laboratories and the need to establish links between the expanded means of digitally aided spatial imagination and the potency of numerically controlled machines for production. The approach is beautifully summed up within the idea of "Prototypical Architecture", presented in the treatise-like description included in one of Marc Fornes's (2011) projects. Regardless of the resulting form, construction technique or the technologies involved, prototypical approach to architecture defines a specific way of architectural research, which encompasses both the aspects of design and construction. In "Persistent Modeling", Phil Ayers (2012) also points out at the contemporary need to reconsider relationships between the three distinct phases of every architectural project: the design, the construction and the use. The joint interpretation of both concepts stated above, offers a way to understand the process of modeling as integral to architectural design as well as construction. This is to suggest that teaching and learning architecture could be based on the design and build approach, which blurs the distinction between the institutions of the studio and the workshop. Today, there are new and promising formats of researching in architecture encompassing practical/ workshop approach which offers itself to better understanding of the elusive "Research by Design" paradigm in architecture. More meaning is given to the notions such as experiment and laboratory in architecture. Further epistemological development of the ways of researching in architecture could once again open up the debate on whether an architectural model could be a self-sufficient and autonomous entity in contrast to its representational role in what is traditionally considered to be a complete architectural project comprised of the design proposal and the constructed object. Thirdly, there is an interest for the reinvented understanding of the material and materiality in architecture. The idea may be traced back to the 60's and the work of Frei Otto who spent his whole life studying the form-finding processes of nature. As explained by Barthel (2005): "The form finding processes are those which given a specified set of conditions and following the prevailing laws of nature, given rise to visible forms and constructions under experimental conditions. As they take place without human intervention, they are also termed autonomous formation processes". Fuelled by the developments in the interdisciplinary field of materials science and engineering, this line of inquiry attracts a growing number of researchers in architecture looking into complex spatial organizations. Peter Eisenman and Anthony Vidler, eds. Stocktaking. Log No.28 (New York: Anyone Corporation, 2013).

Djordje Stojanović, ed. Architectural Education in the Post-Digital Age. Serbian Architecture Journal 5/2 (2013). Jeremy Till, What is architectural research? Three myths and one model (London: R\&D department RIBA, 2007. Available at: http://www.architecture.com/Files/ RIBAProfessionalServices/ResearchAndDevelopment/WhatisArchitecturalResearch.pdf ARbD'14 - Fourth International Conference on Architectural Research by Design. 8th and 9th May 2014 at Fundação Centro Cultural de Belém CCB, Almada Negreiros room, Praça do Império, Lisbon, Portugal (2014).

EAAE 2011. Charter on Architectural Research. (online) Available at: http://www.eaae.be/old/ web_data/documents/research/120903EAAECharterArchitecturalResearch.pdf Ibid.

Ibid.

Ibid.

Richard Blith, Research in Architecture and Design: Framework for a practice based PhD (RMIT University, 2014). (online) Available at: http://www.rmit.edu.au/architecturedesign/ research

Ibid.

Ibid.

Djordje Stojanović, ed. Architectural Education in the Post-Digital Age, Serbian Architecture Journal 5/2 (2013) 
Blith, Richard. Research in Architecture and Design: Framework for a practice based $\mathrm{PhD}$. RMIT University, 2014. (online) Available at: http://www.rmit.edu.au/architecturedesign/ research

EAAE 2011. Charter on Architectural Research. (online) Available at: http://www.eaae.be/old/ web data/documents/research/120903EAAECharterArchitecturalResearch.pdf

Eisenman, Peter and Anthony Vidler. Eds. Stocktaking. Log No28. New York: Anyone Corporation, 2013.

Frayling, Christopher . "Research in Art and Design." Royal College of Art Research Paper 1/1 (1993): 1-5. (online) Available at: http://www.transart.org/wp-content/uploads/groupdocuments/79/1372332724-Frayling_Research-in-Art-and-Design.pdf

Sequeira, J., Matos, J., and Pedros P. Eds. Unifying Academia and Practice through Research. ARbD'14 - Fourth International Conference on Architectural Research by Design. 8th and 9th May 2014 at Fundação Centro Cultural de Belém CCB, Almada Negreiros room, Praça do Império, Lisbon, Portugal, 2014.

Stojanović, Djordje.Ed. Architectural Education in the Post-Digital Age. Serbian Architecture Journal 5/2 (2013).

Stojanovic, Djordje. ' Coffee Futures: Reintroducing Materiality into Architectural Education Curricula." In: Voyatzaki, M. Ed. What's the Matter: Materiality and Materialism at the Age of Computation 498-507. Proceedings of the ENHSA, EAAE International Conference at Escola Tecnica Superior d'Arquitectura de Barcelona, UPC Universitat Politecnina de Catalunya, Barcelona. September 4-6th, 2014.

Till, Jeremy. What is architectural research? Three myths and one model. London: R\&D department RIBA, 2007. (online) Available at: http://www.architecture.com/Files/ RIBAProfessionalServices/ResearchAndDevelopment/WhatisArchitecturalResearch.pdf 
S A J $2014-6$ - 


\section{PITER AJZENMAN,}

\section{ILI KAKO ELIMINISATI ONO ŠTO ČOVEK POSTANE}

\section{Jörg H. Gleiter}

Piter Ajzenman je Ikar post-avangardne arhitekture koji se može pohvaliti brojnim visoko cenjenim, kontroverznim objektima - kao što su Spomenik ubijenim Jevrejima Evrope u Berlinu i Ciudad de la Cultura de Galicia u Santijagu de Kompostela. Kako eliminisati ono što čovek postane-ovo je jedan od načina da se rezimira jedna od presudnih odlika Ajzenmanove arhitektonske prakse: nestanak autora. Pokazujući svoj prezir prema individualnom stilu u umetnosti, Ajzenman je u debatama o arhitekturi redovno potezao pitanje Mišela Fukoa: „Šta je pisac?” Međutim, smrt autora - „la mort de l'auteur” koju je prvi put pomenuo Roland Bart - nije bila sama sebi svrha po Ajzenmanu. Zato što jedino pitanje koje sledi:,Šta je kritika?”, osvetljava ulogu eliminacije autora u negativnosti estetike Ajzenmanove arhitektonske prakse: to je dijalektika kritike razuma i epistemologije. U tom smislu, Ajzenmanova teorija arhitekture predstavlja važan-ako ne nekontroverzan-doprinos kritičkoj filozofiji arhitekture.

KLJUČNE REČI: PITER AJZENMAN, FILOZOFIJA ARHITEKTURE, KRITIČKA TEORIJA, AUTORSTVO, DEKONSTRUKCIJA, PROJEKTOVANJE

OPERATIVNE RAZLIKE.

\section{AJZENMAN, TAFURI I LEKCIJA PIRANEZIJA}

\section{Gabriele Mastrigli, Alessandro Toti}

Piter Ajzenman je arhitekta. Iako povezana sa interesovanjem za razne oblike, oblast njegovog delovanja obuhvata istraživanje teorijskog osnova arhitektonske discipline. Arhitektura, kao artefakt i kao projekat, može da se posmatra kao najočiglednija reprezentacija tradicionalne opozicije zapadne metafizike: odsustva i prisustva. Stoga je zadatak arhitekte, prema Ajzenmanu, da analitički interveniše u ovom dijalektičkom stanju i učini ga operativnim.

Sa ove tačke gledišta, Ajzenmanov pristup disciplini - kao i čitav njegov, celoživotni arhitektonski razvojni put - posmatra se u svetlu dela Đovanija Batiste Piranezija. Otišavši dalje od kritike italijanskog istoričara arhitekture Manfreda Tafurija, Ajzenman je istraživao mogućnost novog tumačenja dijalektike između pozitivnog i negativnog, izbravši pojam zemljišta kao samog mesta ove opozicije. Berlinski Spomenik ubijenim Jevrejima Evrope nudi konačnu reprezentaciju ove dijalektike, čime otvara mogućnost daljeg, neuporedivog rada na njoj.

KLJUČNE REČI: ARHITEKTURA, RAZLIKE, ANALIZA, PROJEKAT, DIJALEKTIKA, REPREZENTACIJA, JEZIK, MONTAŽA, TRAG, ZEMLJIŠTE, SUBJEKT. 
DIGITALNO :

OD KOMPLEKSNOSTI DO JEDNOSTAVNOSTI - I NATRAG

\section{Mario Carpo}

Na početku digitalnog prevrata u ranim 90-tim godinama, digitalno inteligentna arhitektura je uopšteno smatrana krivolinijskom, oblom i modernom. Zašto? Računari su izuzetno svestrane mašine, ali koje ne pokazuju estetičke preferencije. Svakako da Piter Ajzenman, koji je jedan od izumitelja digitalizovanog pravca i 90-tim, nije imao ovo na umu. I zašto se danas stil/pravac digitalno inteligentne arhitekture ponovo menja?

Ovo su (neka od) pitanja koja su obrađena u ovom kratkom radu koji ispituje zašto i kako digitalno kao alat uključuje, ovladava i proizvodi kompleksnost.

KLJUČNE REČI: DIGITALNO, SPLAJNOVI / KRIVE, ALAT, KOMPLEKSNOST, AJZENMAN

\section{ŠTA JE ARHITEKTONSKO ISTRAŽIVANJE DANAS \\ I GDE JE OSNOV?}

\section{Djordje Stojanović}

Zašto graditi velike objekte od gumica sa studentima arhitekture? Na koji način je taj poduhvat povezan sa arhitektonskim obrazovanjem? I ako objekti od gumica nisu ni zgrade, ni modeli, već neka vrsta eksperimenata, kakvu vrstu znanja relevantnog za građevinsku industriju i izgrađeno okruženje oni generišu? Ovo su neka od pitanja koja su postavljena na konferenciji "ISSUES? Concerning the projects of Peter Eisenman" /PITANJA? U vezi sa projektima Pitera Ajzenmana/ koja je održana u Beogradu, u novembru 2013. Ona su povezana sa nizom projektantskih istraživačkih projekata koji su nedavno završeni na Arhitektonskom fakultetu, Univerziteta u Beogradu, i koji su dokumentovani u tematskom izdanju Srpskog arhitektnoskog žurnala pod naslovom „Arhitektonsko obrazovanje u postdigitalnom dobu” koje je objavljeno nezavisno od, ali skoro istovremeno sa održavanjem konferencije. U skladu sa argumentima iznetim u toj publikaciji, ovaj rad će prikazati neke od relevantnih i opšteprihvaćenih teorija i manifesta koji se odnose na metodologije projektantskog istraživanja, pružajući osnov za tekući rad na Arhitektonskom fakultetu, Univerziteta u Beogradu.

KLJUČNE REČI: ARHITEKTONSKO ISTRAŽIVANJE, UMETNIČKO ISTRAŽIVANJE, ISTRAŽIVANJE KROZ PROJEKAT, ISTRAŽIVANJE ZASNOVANO NA PRAKSI 